\title{
Pendampingan Pemanfaatan Aplikasi Media Sosial Sebagai Media Komunikasi Dakwah Pada Masa Pandemi Covid-19 Bagi Takmir Masjid “Baitur Rohmat” Ketawang Gondang Nganjuk
}

\author{
${ }^{1}$ Suhartono, ${ }^{2}$ Anik Indramawan \\ ${ }^{1,2}$ Institut Agama Islam Pangeran Diponegoro Nganjuk \\ 1uhartono@iaipd-nganjuk.ac.id, ${ }^{2}$ anikindramawana12345@gmail.com
}

\begin{abstract}
ABSTRAK
Dakwah merupakan kegiatan keagamaan untuk menyeru dan mengajak umat manusia menuju jalan kebaikan yang ditunjukkan oleh Allah SWT dan Rasul-Nya agar memperoleh kebahagiaan hidup di dunia dan akhirat. Munculnya pandemic covid-19, kegiatan dakwah menghadapi kendala karena tidak dapat dilakukan secara tatap muka. Kegiatan Pengabdian Kepada Masyarakat berupa pendampingan pemanfaatan aplikasi media sosial (handphone android) sebagai media komunikasi dakwah bagi pengurus takmir masjid "Baitur Rohmat" Ketawang Gondang Nganjuk menunjukkan adanya motivasi peserta kegiatan yang tinggi dalam mengikuti kegiatan ini, pemahaman materi, dan keterampilan peserta kegiatan dalam mengoperasikan aplikasi group WhatsApp dan zoom juga dengan hasil yang baik. Berdasarkan hasil kuesioner menunjukkan motivasi peserta mengikuti kegiatan ini sangat baik yaitu $100 \%$, peserta memahami materi pada kegiatan ini adalah $84,62 \%$, dan keterampilan peserta mampu mengoperasikan aplikasi zoom adalah 76,92\%. Pendampingan dalam kegiatan pengabdian kepada masyarakat ini menunjukkan hasil yang baik. Kegiatan dakwah harus tetap eksis dan berjalan seperti biasanya, meskipun dalam situasi dan kondisi pandemi covid-19, yaitu dengan memanfaatkan aplikasi media sosial (group WhatsApp atau zoom) sebagai media komunikasi dakwah.
\end{abstract}

Kata Kunci: Pendampingan, Media Sosial, Komunikasi Dakwah, Pandemic CovId-19

\section{PENDAHULUAN}

Dakwah merupakan bagian yang amat penting di dalam ajaran Islam. Dakwah sebagai kegiatan keagamaan untuk mengajak manusia menuju jalan kebaikan serta memerintahkan mereka berbuat ma"erūf dan mencegah berbuat munkar agar mereka memperoleh kebahagiaan hidup di dunia dan akhirat (Aminudin, 2015). Di dalam Al-Qur'an Surah Ali 'Imran: 104 juga disebutkan bahwa "Dan hendaklah ada di antara kamu segolongan umat yang menyeru kepada kebajikan, menyuruh kepada yang ma'ruf dan mencegah dari yang munkar; merekalah orang-orang yang beruntung” (Departemen Agama RI, 2006). Dakwah 
dapat didefinisikan sebagai sebuah seruan dan ajakan kepada kebaikan yang diperuntukkan bagi seluruh umat manusia.

Dakwah pada hakikatnya merupakan kegiatan yang bertujuan untuk menyeru manusia ke arah yang lebih baik dengan cara yang baik pula, baik dilakukan secara jama'ah maupun individu agar menjadi manusia yang terbaik (Suprima, dkk., 2021). Di dalam Al-Qur'an Surat An-Nahl ayat 125 disebutkan “Serulah (manusia) kepada jalan Tuhan-mu dengan hikmah dan pelajaran yang baik dan bantahlah mereka dengan cara yang baik. Sesungguhnya Tuhanmu Dialah yang lebih mengetahui tentang siapa yang tersesat dari jalan-Nya dan Dialah yang lebih mengetahui orang-orang yang mendapat petunjuk" (Departemen Agama RI, 2006). Kegiatan berdakwah menjadi tugas seluruh umat Islam dan memberi tuntunan bagaimana cara-cara berdakwah dengan hikmah kebijaksanaan untuk menjalankan perintah Allah SWT dan menjauhi segala larangan-Nya. Namun, kegiatan berdakwah menghadapi kendala dengan munculnya wabah Covid-19.

Virus corona yang populer dengan sebutan istilah "Covid-19" telah menjadi perhatian serius masyarakat dunia sejak awal tahun 2020 di kota Wuhan, Hubei, China (Rahman dan Istriyani, 2020; Yuliana, 2020). Hal yang paling ditakutkan dari kasus Covid-19 ini adalah potensi penyebarannya. Meski virus ini tidak seganas dan semematikan sindrom pernapasan akut parah (Severe Acute Respiratory Syndrome, $S A R S$ ), tetapi COVID-19 menyerang lebih banyak orang dengan total kematian beratus kali lipat (Agustino, 2020). Dengan merebaknya wabah covid 19 banyak aktivitas masyarakat berkurang tidak seperti biasanya bahkan ada sebagian daerah menerapkan lockdown sampai waktu yang telah ditentukan, tentu masyarakat tidak bisa menolak harus melakukan aktifitas di rumah (Fauzi dan Maghfiroh, 2020).

Pandemi covid-19 telah mempengaruhi dan menjadi tantangan pada semua bidang kehidupan dan aktivitas masyarakat. Salah satu diantaranya aktivitas berdakwah bagi umat Islam. Hasil penelitian oleh Setyowati \& Cahya (2020) menyebutkan bahwa hadirnya wabah berupa pandemi covid-19 yang masih terjadi saat ini menjadikan seluruh kegiatan menjadi terbatas baik itu ruang gerak, maupun perkumpulan secara langsung, termasuk dalam kegiatan dakwah. Dalam penelitian oleh Baidowi dan Salehoddin (2021) menyebutkan bahwa edaran yang dikeluarkan oleh pemerintah mengenai Work from Home (WFH) bagi seluruh masyarakat Indonesia termasuk para ulama' yang diharuskan untuk melakukan kegiatan keagamaan termasuk dakwah dan lain-lain sebagainya dari tempat tinggal masingmasing. Hasil penelitian oleh Suprima, dkk., (2020) juga menyebutkan bahwa kegiatan dakwah yang biasa dilakukan di masjid, lapangan, mimbar, dan lain-lain, dengan jumlah hadirin yang banyak, tentu tidak bisa dilakukan seperti biasanya karena peraturan pemerintah mengenai PSBB dimana masyarakat dilarang menyelenggarakan kegiatan yang menyebabkan kerumunan orang banyak yang dapat mempercepat penyebaran penularan covid-19. 
Dalam situasi dan kondisi apapun termasuk adanya pandemic covid-19 , kegiatan dakwah harus tetap dilakukan. Enjang \& Aliyuddin (2009) menyatakan kegiatan dakwah merupakan proses penyampaian ajaran agama Islam kepada umat manusia di setiap ruang dan waktu dengan berbagai metode dan media yang sesuai dengan situasi dan kondisi para penerima ( $m a d ' u$ ) dakwah tersebut. Seiring adanya pandemic dan pembatasan kegiatan masyarakat, kegiatan dakwah dapat dilakukan dengan memanfaatkan media sosial yang berkembang sekarang ini.

Media sosial merupakan salah satu media online yang mendukung interaksi sosial dan berkomunikasi dengan menggunakan teknologi berbasis web. Jenis aplikasi media sosial, di antaranya facebook, twitter, line, bbm, whatsApp, instagram, path, linkedin, snapchat dan yang lainnya (Trisnani, 2017). Aplikasi whatsApp sebagai salah satu fitur yang terdapat dalam smartphone/ handphone berbasis android. Aplikasi whatsAap ini banyak digunakan oleh masyarakat dunia dan memberikan banyak kemudahan untuk berkomunikasi dan penyampaian pesan, dimana aplikasi ini dapat digunakan sebagai media chatting, call, dan video call, yang disertai dengan kemampuan pengiriman dokumen foto, video dan file serta audio (Saputra, 2020). Oleh karena itu, kegiatan dakwah di tengah pandemic agar tetap eksis, dapat memanfaatkan media sosial dengan aplikasi WhatApp.

Kegiatan dakwah pada masa pandemic seperti sekarang ini, belum dapat dikelola secara maksimal oleh pengurus takmir masjid Baitur Rohmat Ketawang, karena berbagai faktor yang menjadi penyebabnya, salah satu diantaranya masih belum pernah menggunakan handphone berbasis android untuk komunikasi dakwah. Oleh karena itu perlu dilakukan pendampingan agar kegiatan dakwah dapat berjalan dan tetap eksis seperti biasanya.

Pendampingan dilakukan oleh Tim Pengabdian Kepada Masyarakat (PKM) IAI Pangeran Diponegoro Nganjuk kepada pengurus takmir masjid. Pendampingan yang dilakukan sebagai wujud pengabdian kepada masyarakat. Dengan Pengabdian Kepada Masyarakat (PKM) ini dapat memecahkan permasalahan yang dihadapi oleh pengurus takmir masjid dalam melaksanakan dakwah di tengah pandemic covid-19. Pengabdian ini juga dapat memberikan dampak positif kepada pengurus takmir masjid, agar dapat menjalankan kegiatan dakwah secara online dengan media handphone android, sehingga kegiatan dakwah tetap eksis dan berjalan seperti biasanya, meskipun di tengah pandemic covid-19.

\section{METODE PENELITIAN}

Metode yang digunakan pada kegiatan Pengabdian Kepada Masyarakat (PKM) ini adalah metode Participatory Learning and Action (PLA) atau proses belajar dan praktik secara partisipatif. Metode ini merupakan metode baru pemberdayaan masyarakat yang dahulu dikenal sebagai "Learning by doing". Dalam metode Participatory Learning and Action (PLA) terdapat proses belajar 
melalui: ceramah, diskusi, curah pendapat, dan sebagainya. Darmawan dan Rosmilawati (2020) menyatakan bahwa metode Participatory Learning and Action (PLA) merupakan pendekatan pemberdayaan yang memiliki keunggulan baik secara filosofis maupun nilai aksi dengan mengutamakan pada proses belajar Bersama.

Kegiatan Pengabdian Kepada Masyarakat (PKM) bertempat di Masjid Baitur Rohmat Ketawang, Gondang, Nganjuk. Peserta kegiatan ini adalah seluruh anggota takmir masjid Baitur Rohmat Ketawang berjumlah 13 peserta, yang terdiri dari unsur tanfidiyah, muslimat, fatayat, dan remaja masjid.

Pelaksanaan kegiatan pengabdian kepada masyarakat ini, meliputi tiga tahapan diantaranya (1) tahap pertama, narasumber memberikan materi tentang peran penting media social sebagai media dakwah di masa pandemic covid-19. Metode yang digunakan oleh narasumber adalah metode ceramah, curah pendapat, dan diskusi, (2) tahap kedua, narasumber memberikan pendampingan mengoperasikan media handphone berbasis android untuk komunikasi dakwah, dengan mengembangkan grup whatsapp dan zoom. Metode yang digunakan adalah praktek dan pendampingan, dan (3) tahap ketiga, narasumber memberikan evaluasi dan refleksi terhadap kegiatan Pengabdian Kepada Masyarakat (PKM) yang telah dilaksanakan. Metode yang digunakan oleh narasumber adalah ceramah variatif. Pada akhir kegiatan, narasumber memberikan angket/kuesioner berkaitan dengan kegiatan pendampingan yang telah dilaksanakan.

\section{HASIL DAN PEMBAHASAN}

Pendampingan pemanfaatan aplikasi media sosial sebagai media komunikasi dakwah bagi takmir masjid "Baitur Rohmat" desa Ketawang Gondang Nganjuk dilaksanakan dengan beberapa kegiatan. Pada tahap awal, narasumber memberikan materi peran penting media sosial sebagai media komunikasi dakwah di masa pandemic covid-19 secara klasikal secara tatap muka dengan protokol kesehatan. Materi yang disampaikan oleh narasumber, di antaranya hakikat aplikasi media social whatsApp dan zoom, peran penting media social sebagai media komunikasi dakwah, dan teknik mengoperasikan aplikasi WhatsApp dan zoom sebagai media komunikasi dakwah. Hambatan pada kegiatan pemberian materi adalah keterbatasan waktu pertemuan, sehingga waktu untuk kegiatan molor melebihi dari waktu yang telah terjadwal. Solusi mengatasi hambatan tersebut, narasumber memberikan waktu untuk konsultasi jika ada hal-hal yang belum dipahami oleh peserta kegiatan, Konsultasi dapat dilakukan melalui grup whatsapp dan kontak pribadi,

Pada kegiatan berikutnya adalah pendampingan penggunaan aplikasi WhatsApp dan zoom sebagai media komunikasi dakwah, meliputi pendampingan praktek menggunakan aplikasi WhatsApp dan zoom. Hambatan yang terjadi pada pendampingan praktek mengoperasikan media WhatsApp dan zoom adalah ada sebagian dari peserta kegiatan yang masih kebingungan mengoperasikan handphone 


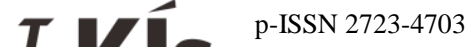

android. Hal ini dipengaruhi oleh faktor usia dan belum pernah menggunakan handphone android. Solusi yang dilakukan oleh narasumber adalah peserta kegiatan yang masih ada kendala agar bergabung takmir yang sudah dapat mengoperasikannya.

Pada tahap akhir kegiatan Pengabdian Kepada Masyarakat (PKM), narasumber melakukan evaluasi dan refleksi terhadap kegiatan Pengabdian Kepada Masyarakat (PKM) yang telah dilaksanakan. Akhir kegiatan, peserta kegiatan pendampingan diberikan angket/ kuesioner berkaitan dengan kegiatan pendampingan penggunaan media social sebagai media komunikasi dakwah yang telah dilaksanakan.

Hasil analisis dari kuesioner yang dibagikan kepada peserta kegiatan pendampingan terdiri dari tiga indikator di antaranya motivasi, pemahaman, dan keterampilan mengoperasikan media social sebagai media komunikasi dakwah. Dari 13 peserta kegiatan ini, persentase untuk indikator motivasi mengikuti kegiatan pendampingan penggunaan media social sebagai media komunikasi dakwah adalah $100 \%$, indikator pemahaman materi adalah $84,62 \%$, dan indikator keterampilan mengoperasikan media sosial (handphone android) adalah 76,92\%. Untuk lebih jelasnya dapat dilihat pada tabel berikut:

Tabel 1. Hasil Angket Pelaksanaan Pengabdian Kepada Masyarakat

\begin{tabular}{|l|l|l|}
\hline \multicolumn{1}{|c|}{ Indikator } & \multicolumn{1}{c|}{ Jumlah Peserta } & Persentase \\
\hline Motivasi peserta kegiatan & 13 orang & $100 \%$ \\
\hline Pemahaman materi & 11 orang & $84,62 \%$ \\
\hline Keterampilan peserta kegiatan & 10 orang & $76,92 \%$ \\
\hline
\end{tabular}

Hasil Angket Pelaksanaan Pengabdian Kepada Masyarakat juga dapat dijelaskan dalam histogram berikut:

\section{Gambar. 1. Histogram Hasil Angket Pengabdian Kepada Masyarakat}

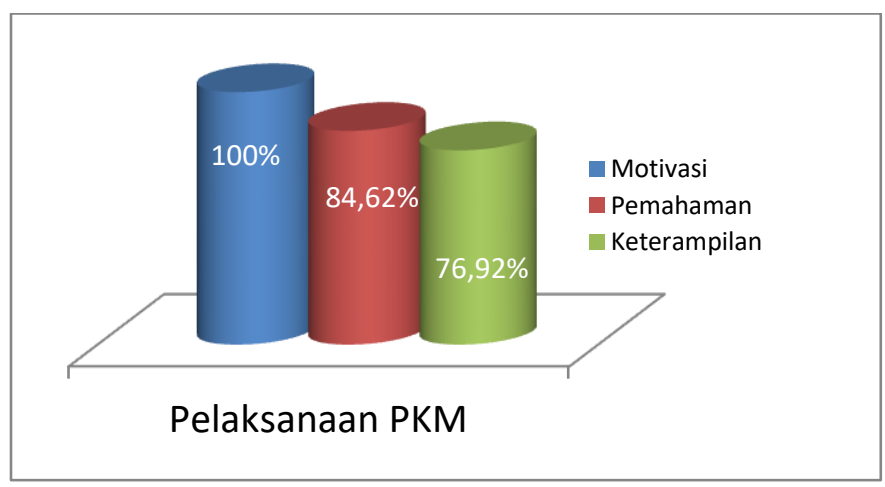

Berdasarkan histogram di atas, dapat dijelaskan bahwa motivasi peserta kegiatan ini sangat baik. Dimana dari 13 peserta kegiatan, semuanya mempunyai 
motivasi yang tinggi untuk mengikuti kegiatan seperti ini. Selanjutnya, pemahaman peserta terhadap materi media sosial sebagai media komunikasi dakwah yang disampaikan oleh narasumber dalam kategori baik, dimana ada 11 peserta telah memahami materi. Sedangkan, keterampilan mengoperasikan media handphone android juga dalam kategori baik, dimana ada 10 peserta telah mampu mengoperasikannya. Dengan demikian, kegiatan pendampingan pada pengabdian kepada masyarakat ini menunjukkan hasil yang baik, sehingga kegiatan pengabdian seperti ini perlu ditindaklanjuti yang lebih baik lagi.

Pelaksanaan PKM ini telah sesuai dengan jadwal dan sasaran yang telah ditentukan. Semua peserta juga semangat mengikuti kegiatan ini. Selain itu, kegiatan PKM ini dilaksanakan dengan suasana penuh kekeluargaan, sehingga memberikan kesan positif pada capaian kegiatan ini.

Merujuk hasil pelaksanaan kegiatan Pengabdian Kepada Masyarakat (PKM) ini, suasana yang nyaman dan tidak membosankan merupakan sesuatu yang penting untuk diciptakan pada suatu kegiatan apapun. Pendampingan ini sebagai proses pembelajaran kepada masyarakat, agar mampu menggunakan media social untuk berdakwah di masa pandemic. Dengan keterampilan menggunakan media sosial (handphone Android) untuk group WhatsApp dan zoom, kegiatan dakwah tetap berjalan meskipun dalam suasana pandemic, Hasil penelitian oleh Fauzi dan Maghfiroh (2020) menyatakan pemanfaatan kemajuan teknologi adalah salah satu sarana alternatif yang memungkinkan di tengah kebijakan lockdown saat ini, menggantikan dakwah yang menyangkut interaksi langsung dengan orang banyak. Adapun dakwah Islam harus tetap mewarnai seluruh kehidupan ummat dan mengisi peluang-peluang yang ada, walaupun tantangan virus Covid-19 ada.

Motivasi peserta untuk belajar dalam kegiatan PKM ini merupakan salah satu faktor penting dalam mencapai tujuan yang diharapkan. Motivasi merupakan suatu dorongan yang menimbulkan hasrat dan minat melakukan sebuah aktivitas untuk mencapai tujuan tertentu (Turabik \& Baskan, 2015). Keberhasilan peserta dalam kegitan PKM ini dipengaruhi oleh tinggi rendahnya motivasi peserta dalam kesungguhan belajar pada kegiatan pendampingan ini. Hasil penelitian oleh Suhartono (2019) menyebutkan bahwa terdapat perbedaan seseorang yang mempunyai motivasi tinggi dan motivasi rendah dalam memahami suatu konsep, dimana seseorang yang mempunyai motivasi tinggi lebih baik daripada seseorang yang mempunyai motivasi rendah dalam memahami suatu konsep. Peserta pada kegiatan pengabdian kepada masyarakat ini mempunyai motivasi yang tinggi, sehingga berdampak pada pemahaman dan keterampilan peserta dalam menggunakan media sosial (handphone android) untuk group WhatsApp dan zoom sebagai media komunikasi dakwah pada masa pandemic ini.

Pemahaman merupakan kemampuan untuk menerangkan dan menginterprestasikan sesuatu (Iriyanti, Haji, \& Zamzaili, 2017). Menurut Anderson dan Krathwohl (2010) dalam Suhartono \& Indramawan (2020) menyatakan 
seseorang yang belajar dikatakan memiliki suatu pemahaman, apabila dapat mengkonstruksi makna dari pesan-pesan pembelajaran, baik yang bersifat lisan, tulisan ataupun grafis, yang disampaikan melalui pengajaran, buku, atau layar komputer. Dengan pemahaman tentang penggunaan aplikasi media social (handphone android), seseorang (peserta) akan mudah mengoperasikan aplikasi WhatsApp dan zoom tersebut. Pemahaman dan keterampilan peserta kegiatan dalam mengoperasikan aplikasi WhatsApp dan zoom, dapat memberikan pengaruh positif kepada peserta kegiatan PKM agar melek teknologi dan tetap berdakwah secara online, dimana tugas dakwah merupakan tanggung jawab bersama di antara kaum muslimin.

Kegiatan akhir/ penutupan Pengabdian Kepada Masyarakat (PKM), pihak ketua dan pengurus takmir menyampaikan terima kasih kepada para narasumber yang telah membantu memberikan pendampingan penggunaan aplikasi group WhatsApp dan zoom sebagai media dakwah. Kegiatan pengabdian kepada masyarakat telah berjalan lancar dan memberikan banyak perubahan kepada peserta, baik pemahaman dan keterampilan mengoperasikan aplikasi group WhatsApp dan zoom sebagai media dakwah.

Dakwah Islam harus tetap eksis dilaksanakan di tengah pandemi virus Covid19 dengan berbagai alternatif. Salah satu alternatif adalah memanfaatkan aplikasi group WhatsApp dan zoom untuk menjadi perantara dakwah di tengah pembatasan akses interaksi yang terjadi saat ini.

\section{SIMPULAN DAN SARAN}

Hasil dari kegiatan pengabdian kepada masyarakat melalui pendampingan pemanfaatan aplikasi media sosial (handphone android) sebagai media komunikasi dakwah bagi pengurus takmir masjid "Baitur Rohmat" Ketawang Gondang Nganjuk menunjukkan adanya motivasi peserta kegiatan yang tinggi mengikuti kegiatan ini, pemahaman materi, dan keterampilan peserta kegiatan dalam mengoperasikan aplikasi group WhatsApp dan zoom juga dengan hasil yang baik. Berdasarkan hasil kuesioner menunjukkan motivasi peserta mengikuti kegiatan ini sangat baik yaitu $100 \%$, peserta memahami materi pada kegiatan ini adalah $84,62 \%$, dan keterampilan peserta mampu mengoperasikan aplikasi zoom adalah 76,92\%. Hasil pendampingan dalam kegiatan pengabdian kepada masyarakat ini menunjukkan hasil yang baik. Saran kepada ketua takmir masjid agar kegiatan dakwah harus tetap berjalan seperti biasanya, meskipun dengan aplikasi group WhatsApp atau zoom. Selain itu, kegiatan pelatihan atau pendampingan yang menunjang kegiatan keagamaan dan perkembangan dakwah Islamiyah perlu terus dilakukan dengan mengikuti perkembangan zaman. 


\section{DAFTAR PUSTAKA}

Agustino, Leo. (2020). Analisis Kebijakan Penanganan Wabah Covid-19: Pengalaman Indonesia. Jurnal Borneo Administrator, 16 (2); 253-270.

Aminudin. (2015). Dakwah dan Problematikanya dalam Masyarakat Modern. AlMunzir, 8(1); 14-28.

Baidowi, Ach. dan Salehoddin, Moh. (2021). Strategi Dakwah di Era New Normal. Jurnal Muttaqien, 2. (1); 58 - 74.

Darmawan, Dadan \& Rosmilawati, Ila. (2020). Participatory Learning And Action (PLA) pada Kelompok Keluarga Harapan di Kota Serang. Prosiding. Seminar Nasional Pendidikan FKIP Universitas Sultan Ageng Tirtayasa, 3(1); 570-579.

Departemen Agama RI. (2006). Al Qur'an Dan Terjemahan Bahasa Indonesia, Menara Kudus, Kudus.

Enjang, AS. dan Aliyuddin. (2009). DasarDasar Ilmu Dakwah Pendekatan Filosofis dan Praktis, Bandung: Widya Padjadjaran.

Fauzi, Ahmad \& Maghfiroh, Eva. (2020). Problematika Dakwah Ditengah Pandemi Covid-19. Alhikmah, 18 (1); 23-32.

Iriyanti, R., Haji, S., \& Zamzaili. (2017). Kemampuan Pemahaman Konsep Dan Penalaran Adaptif Pada Siswa Kelas VII SMP Negeri 2 Lubukliggau Yang Diajar Melalui Pendekatan Pembelajaran Matematika Realistik Dengan Tipe Structure Dyadic Method. Jurnal Pendidikan Matematika Raflesia, 2(1); 65-82.

Rahman, Muhammad Fathur \& Istriyani, Ratna. (2020). Representasi Masyarakat Aktif di Masa Pandemi Covid-19 (Studi Ekonomi dan Sosial Keberagamaan di Bausasran Danurejan Yogyakarta). Jurnal Penelitian, 14(2); 185-216.

Sepriadi Saputra. (2020). Efektivitas Komunikasi Interpersonal Dalam Kegiatan Pembelajaran Melalui Media Whatsapp Group. Jurnal Professional FIS UNIVED, 7 (1); 11-21.

Setyowati \& Cahya, A. (2020). Peran Dakwah Daring untuk Menjaga Solidaritas Sosial di Masa Pandemi Covid 19. Academica Journal of Multidisciplinary Studies, 4(2); 295-310.

Suhartono, (2019). Pengaruh Model Group Investigation dan Motivasi Berprestasi Terhadap Pemahaman Konsep. Disertasi, Universitas Negeri Malang,Tidak Diterbitkan.

Suhartono \& Indramawan, Anik. (2020). An Analitic Study: Affectivity Of Group Investigation Model On Student Understanding Technique Writing A Paper In Study Program Islamic Education Religion. JALIE: Journal of Applied Linguistic and Islamic Education, 4 (2); 93-105.

Suprima, dkk. (2021). Dakwah di Masa Pandemi Covid-19: Eksistensi, problematika serta solusi. Jurnal Ilmu Dakwah, 41 (1); 85-96. 
Trisnani. (2017). Pemanfaatan WhatsApp sebagai Media Komunikasi dan Kepuasan Dalam Penyampaian Pesan Dikalangan Tokoh Masyarakat. Jurnal Komunikasi, Media Dan Informatika, 6(November), 1-12

Turabik, T., \& Baskan, G. A. (2015). The Importance of Motivation Theories in Terms Of Education Systems. Procedia - Social and Behavioral Sciences, 186; 1055-1063.

Yuliana. (2020). Corona virus diseases (Covid-19); Sebuah tinjauan literatur. Wellness And Healthy Magazine, 2 (1); 187-192. 